\title{
Konjenital Kalp Hastalıklarında Respiratuar Sinsisyal Virüs Proflaksisinde Uygulama Protokolünün Hasta Uyumu Üzerine Etkisi ve Klinik Sonuçları
}

\author{
The Effects of Respiratory Syncytial Virus Prophylaxis Application Protocol on Patient Compliance \\ and Clinical Outcomes in Congenital Heart Diseases
}

\author{
Öykü İsal TOSUN ${ }^{1}$ \\ 1. Istanbul Medeniyet Üniversitesi Tıp Fakültesi, Çocuk Kardiyoloji Bilim Dalı, İstanbul, Türkiye
}

\section{$\ddot{O Z Z T}$}

Amaç: Palivizumab, yüksek riskli çocuklarda respiratuar sinsisyal virüs (RSV) önlenmesinde iyi tolere edilen, güvenli bir monoklonal antikordur. Hastalarin zamaninda ve tam doz proflaksi alabilmeleri için anne ve babanın uуuтu son derece önemlidir. RSV proflaksisinde hasta uyumunu ve klinik sonuçlarını değerlendiren makaleler bulunmaktadır. Her kliniğin kendi takip ve uygulama protokolü bulunmaktadır ancak kullanılan protokoller, hasta uyumu ve doz tamamlanması ile ilgili bir çalışma bulunmamaktadir.

Gereçler ve Yöntem: Ekim 2016-Mart 2018 tarihleri arasinda çocuk kardiyoloji polikliniğinde RSV proflaksisi endikasyonu almıs hemodinamik olarak anlamlı KKH'na sahip 2 yas alt toplam 60 hastaya ait veriler çocuk kardiyoloji poliklinik ve servis kayltlarından retrospektif olarak incelendi. 2 farkl sezonda, proflaksi endikasyonu alan ve 2 farkl protokol ile takip edilen hastalar uyum ve klinik sonuçlar açısından birbiriyle karşılaștırıldı. Tam uyum, sezon boyunca 5 aylık dönemde, 30 gün aralarla en az 4 doz palivizumab uygulaması yapılmasi olarak tanımland

Bulgular: Ekim 2016- Mart 2017 sezonunda, 5 ayllk dönemde uygulan ortalama doz $1 \pm 0.2$ doz idi ve tam hasta uyumu \%10 olarak bulundu. Doz aralıklarl $37.2 \pm 6.15$ gün olarak bulundu. 10 hastada (\%40) ASYE nedeniyle hastaneye yatıs ve RSV izolasyonu mevcuttu. Ekim 2017-Mart 2018 sezonunda yapılan protokol değisikliği sonrası, hasta uyumu \%100 olarak değerlendirildi, ASYE nedeniyle acil servis başvurusu ve hastaneye yatış gereksinimi tespit edilmedi.

Sonuç: Palivizumab proflaksisinde doz tamamlanması ve arallğ uyumunu arttırmak RSV'ye bağll hastane yatışlarını önemli ölçüde azaltmaktadır. Detaylı ve iyi organize edilmis takip ve uygulama protokolleri hazırlanmak uyumu arttırmada son derece önemlidir

Anahtar Kelimeler: respiratuar sinsisyal virus, konjenital kalp hastalıklarl, uyum

\section{ABSTRACT \\ Objective: Palivizumab is a well tolerated, safe monoclonal an- tibody in the prevention of respiratuar syncytial virus (RSV) in high-risk children. The adaptation of the parents is extremely important for patients to be able to receive timely and full dose prophylaxis. There are articles evaluating patient compliance and clinical outcomes in RSV prophylaxis. Each clinic has its own follow-up and administration protocol, but there are no studies on the protocols used, patient compliance and dose completion.}

İletişim

Sorumlu Yazar: Öykü İsal TOSUN, Dr. Öğretim Üyesi

Adres: İstanbul Medeniyet Ünv. Tıp Fakültesi, Cocuk Kardiyoloji B.D.

Ünalan Sok, D-100 Karayolu Yanyol, Üsküdar, İstanbul, Türkiye

Tel: +90 (505) 3901685

E-Posta: isaltosun@hotmail.com

Makale Gelis: 11.12.2018

Makale Kabul: 21.01.2019

DOI: http://dx.doi.org/10.16948/zktipb.495665
Material and Methods: A total of 60 patients with hemodynamically significant congenital heart disease who had RSV prophylaxis in the pediatric cardiology outpatient clinic between October 2016 and March 2018 were retrospectively reviewed. The patients who received prophylaxis in 2 different seasons and were followed up with 2 different protocols were compared with each other in terms of compliance and clinical results.

Results: In the October 2016-March 2017 season, the mean dose was $1 \pm 0.2$ in the 5 -month period and full patient compliance was $10 \%$. Dose intervals were $37.2 \pm 6.15$ days. 10 patients (40\%) were hospitalized. After the protocol change was made in the October 2017-March 2018 season, patient compliance was evaluated as $100 \%$.

Conclusion: In palivizumab prophylaxis, increasing the dose and increasing the compliance of the interval significantly decreases hospitalizations due to $R S V$. Detailed and well-organized follow-up and application protocols are extremely important in increasing compliance.

Keywords: respiratory syncytial virus, congenital heart diseases, compliance

\section{GíRiş}

Respiratuar sinsisyal virüs (RSV) bebeklik ve erken çocukluk döneminde alt solunum yolu enfeksiyonlarının (ASYE) önemli bir nedenidir ve iki yaşına kadar neredeyse tüm çocuklar enfekte olmaktadırlar (1). RSV enfeksiyonu yaşamın ilk yılında tüm dünyada hastaneye yatışların ve morbiditenin ortak bir nedenidir (2). Prematurite, kronik bronkopulmoner hastalık, hemodinamik olarak anlamlı konjenital kalp hastalığı $(\mathrm{KKH})$, nöromüskuler hastalıklar, immun sistem bozuklukları gibi hastalıklara sahip çocuklar RSV enfeksiyonu için yüksek risk grubu olarak ağır enfeksiyon adayıdır $(3,4)$. Hemodinamik anlamlı KKH'na sahip çocuklarda RSV enfeksiyonunda hastane yatışı süresi, yoğun bakım takibi ve mekanik ventilatör ihtiyac1, operasyon öncesi ve sonrası komplikasyon oranları artmaktadır $(5,6)$.

RSV sezonu coğrafi özelliklere göre dünyada farklı zamanlarda görülmektedir; ayrıca aynı coğrafi bölgede de her y1l farkl1lıklar gösterebilir. Ülkemizin de içinde bulunduğu kuzey yarımküredeki RSV sezonunun başlama zamanı Kasım- Aralık, tepe aktivitesi Ocak-Şubat, sonlanması Mart-Nisan aylarıdır. Salgınların süresi 5-6 ay devam etmekte$\operatorname{dir}(7)$

RSV enfeksiyonuna bağlı ASYE'larının tedavisinde etkin bir tedavi bulunmamaktadır. Palivizumab, yüksek riskli çocuklarda RSV önlenmesinde iyi tolere edilen, güvenli bir monoklonal antikordur ve 1998 y1lında Food and Drug Administration 
(FDA) onayı almıştır (8). Hemodinamik anlamlı KKH'larını içeren randomize çalışmalarda RSV'ye bağlı hastane yatıșlarının azaltılmasında palizumab proflaksisinin oldukça etkin olduğu gösterilmiştir $(9,10)$.

Palivizumab yarılanma ömrü yaklaşı $20 \mathrm{ol}-$ duğundan RSV sezonu boyunca korunma sağlanabilmesi için aylık enjeksiyonlar şeklinde 5 doz aşı uygulanması önerilmektedir. İki yaş altında, aylık $15 \mathrm{mg} / \mathrm{kg} / \mathrm{doz}$ palivizumab uygulandığında ilk enjeksiyondan sonra serum RSV antikor düzeyi 37 mikrogram/mililitre, ikinci enjeksiyondan sonra $57 \mathrm{mikrogram} / \mathrm{mililitre,} 3$. enjeksiyondan sonra 68 mikrogram/mililitre ve 4 . enjeksiyondan sonra 72 mikrogram/mililitre olarak bulunmuştur. 40 mikrogram/mililitre serum RSV antikor düzeyi sağlandığında akciğerlerde RSV replikasyonunun \%99 azaldığı gösterilmiştir (11).

Hastaların zamanında ve tam doz proflaksi alabilmeleri için anne ve babanın uyumu son derece önemlidir. RSV proflaksisinde hasta uyumunu ve klinik sonuçlarını değerlendiren makaleler bulunmaktadır (12-14). Ülkemizde çocuk kardiyoloji poliklinklerinde, 2 yaş altındaki hemodinamik anlamlı konjenital kalp hastalığına sahip çocuklarda, EkimMart aylarında bir ay ara ile palivizumab proflaksisi yapılmaktadır. Her çocuk kardiyoloji kliniğinin kendi takip ve uygulama protokolü bulunmaktadır. $\mathrm{Bu}$ kliniklerde kullanılan protokoller, hasta uyumu ve doz tamamlanması ile ilgili bir ülkemizden çalışma bulunmamaktadır.

Biz çalışmamızda, ardışık iki sezonda (EkimMart 2016-2017; Ekim-Mart 2017-2018) palivizumab proflaksi alan hemodinamik anlamli KKH'lı çocuklarda uygulanan iki farklı takip ve uygulama protokolünün hasta uyumu ve klinik sonuçlar üzerine etkisini araştırmayı amaçladık.

\section{GEREÇ ve YÖNTEM}

Ekim 2016-Mart 2018 tarihleri arasında çocuk kardiyoloji polikliniğinde RSV proflaksisi endikasyonu almış hemodinamik olarak anlamlı KKH'na sahip 2 yaş altı toplam 60 hastaya ait veriler çocuk kardiyoloji poliklinik ve servis kayıtlarından retrospektif olarak incelendi.

Çalışma hastanemiz etik kurulundan 2018/0466 numaralı etik kurul onayı alınarak yapı1miştır.

Hastaların aşı dozu uygulanması için hastaneye başvurup başvurmadığ 1 belirlenerek kaydedildi. Alınan anamnez kayıtlarından RSV sezonu boyunca ASYE nedeniyle hastanede yatış olup olmadığı, uzunluğu, yoğun bakım ihtiyac1, mekanik ventilatöre bağlanma ihtiyacı ve süresi sorgulanarak kaydedildi. Hastane yatışı sırasında RSV izolasyonu yapılan hastalar ayrı olarak kaydedildi. Hastaların sezon boyunca toplam kaç doz aşı uygulaması aldı̆̆ 1 ve doz aralıkları poliklinik kayıtlarından belirlenerek kayıt edildi. Doz tamamlanması sirasinda KKH nedeni ile opere olan hasta var ise anamnez kayıtlarından taranarak belirlendi.

Ekim 2016- Mart 2017 ve Ekim 2017-Mart 2018 sezonlarında çocuk kardiyoloji palivizumab takip ve uygulama protokellerinde yapılan deği- şiklikler ayrı ayrı incelenerek, yapılan değişiklikler detaylı olarak kaydedildi. 2 farklı sezonda, proflaksi endikasyonu alan ve 2 farkli protokol ile takip edilen hastalar uyum ve klinik sonuçlar açısından birbiriyle karşılaştırıldı. Tam uyum, sezon boyunca 5 aylık dönemde, 30 gün aralarla en az 4 doz palivizumab uygulaması yapılması olarak tanımland.

\section{İstatiksel Analiz}

İstatiksel Analiz NCSS 2007 paket program ile yapıldı. Verilerin değerlendirilmesinde tanımlayıcı istatistiksel metotların (ortalama, standart sapma) yanı sıra ikili grupların karşılaştırılmasında bağımsız t testi, nitel verilerin karşılaştırılmasında ki-kare testi. Sonuçlar, anlamlılık $\mathrm{p}<0,05$ düzeyinde değerlendirildi.

\section{BULGULAR}

Çalışmaya alınan toplam 60 hastanın tamamlanan ortalama gestasyon haftalar1 $38 \pm 0.16$ idi. Ekim 2016-Mart 2017 sezonunda (1. sezon) hemodinamik olarak anlamlı KKH'1 olan ve palivizumab proflaksisi endikasyonu almış 25 hasta (12 erkek; $13 \mathrm{k1z}$ ) ve Ekim 2017- Mart 2018 sezonunda (2. sezon) hemodinamik olarak anlaml KKH'1 olan ve palivizumab proflaksisi endikasyonu 35 (17 erkek; $18 \mathrm{k} 1 z)$ hasta çalışmaya dahil edildi.

Sezon 1'de çalışmaya alınan toplam 25 hastanın ortalama yaşları $4 \pm 1.1$ ay, sezon 2'de ki hastaların yaş ortalamaları $10.8 \pm 1.04$ ay idi. 10 hasta hemodinamik anlamlı Ventriküler Septal Defekt (VSD) (\%40), 6 hasta Büyük Arterlerin Transpoziyonu (BAT) (\%24), 5 hasta Fallot Tetralojisi (TOF) (\%20), 2 hasta Çift Girişli Sol Ventrikül (DILV) (\%8), 2 hasta Hipoplastik Sol Kalp Sendromu (HLHS) (\%8) nedeniyle proflaksi endikasyonu almış idi. BAT, TOF, DILV ve HLHS tanısı olan hastaların tamamı postoperatif dönemde proflaksi endikasyonu olmuş hastalar iken VSD tanısı almış hastaların hepsi hemodinamik olarak anlamlı ancak operasyon endikasyonu bulunmayan ve medikal tedavi ile takip edilmekte olan hastalard.

Sezon 2'de, 1 hasta (\%2.8) Fallot Pulmoner Kapak Yokluğu (TOF-APV), 4 hasta (\%11.4) HLHS, 4 hasta (\%11.4) DILV, 15 hasta (\%42.8) hemodinamik anlamlı VSD, 6 hasta (\%17.1) BAT, 5 hasta (\%14.2) Intakt Ventriküler Septumlu Pulmoner Atrezi (IVS-PA) nedeniyle proflaksi endikasyonu almış idi. TOF-APV, HLHS, DILV, BAT tanilı hastaların hepsi postoperatif dönemde takipte idi, IVS-PA tanilı hastalar duktus arteriosusa stent uygulanması sonrası takipte idi. VSD tanısı almış hastaların hepsi hemodinamik olarak anlamlı ancak operasyon endikasyonu bulunmayan ve medikal tedavi ile takip edilmekte olan hastalardı. Çalışmaya dahil edilen hastalara ait demografik veriler Tablo 1 de özetlenmiştir.

Ekim 2016 - Mart 2017 sezonunda; hastalara Mart ayında palivizumab proflaksisi endikasyonu tek bir çocuk kardiyoloji hekimi tarafindan konulduktan sonra ilk doz uygulanması çocuk acilde yapildı. Palivizumab proflaksisi alan hastalar ilk uygulamada ayrı olarak kaydedildi ve aileler 1 ay sonra doz tekrarı için çocuk kardiyoloji polklinik 
Tablo 1: Hastaların Demografik Özellikleri.

\begin{tabular}{|c|c|c|c|c|}
\hline & \multicolumn{2}{|c|}{ 1.sezon (n: 25) } & \multicolumn{2}{|c|}{ 2.sezon $(\mathrm{N}: 35)$} \\
\hline \multirow{2}{*}{ Cinsiyet } & $\mathrm{K} 1 \mathrm{z}$ & 13 & $\mathrm{~K} 1 \mathrm{z}$ & 18 \\
\hline & Erkek & 12 & Erkek & 17 \\
\hline Yaş (ay) & \multicolumn{2}{|l|}{$4 \pm 1.1$} & \multicolumn{2}{|c|}{$10.8 \pm 1.04$} \\
\hline VSD & \multicolumn{2}{|c|}{$10(\% 40)$} & \multicolumn{2}{|c|}{$15(\% 42.8)$} \\
\hline BAT & \multicolumn{2}{|c|}{$6(\% 24)$} & \multicolumn{2}{|c|}{$6(\% 17.1)$} \\
\hline TOF & \multicolumn{2}{|c|}{$5(\% 20)$} & & \\
\hline DILV & \multicolumn{2}{|l|}{$2(\% 8)$} & \multicolumn{2}{|c|}{$4(\% 11.1)$} \\
\hline HLHS & \multicolumn{2}{|l|}{$2(\% 8)$} & \multicolumn{2}{|c|}{$4(\% 11.1)$} \\
\hline TOF-APV & & & \multicolumn{2}{|c|}{$1(\% 2.8)$} \\
\hline IVS-PA & & & \multicolumn{2}{|c|}{$5(\% 14.2)$} \\
\hline
\end{tabular}

VSD: Ventriküler septal defekt, BAT: Büyük arterlerin transpoziyonu, TOF: Fallot tetralojisi, DILV: Çift girişli sol ventrikül, HLHS: Hipoplastik sol kalp sendromu, TOF-APV: Fallot pulmoner kapak yokluğu, IVS-PA: İntakt ventriküler septumlu pulmoner atrezi

kontrolüne çağrıldı. 1 ay sonra poliklinik kontrolüne gelen hastalara doz tekrarı yapıld1. 5 aylık dönemde uygulan ortalama doz $1 \pm 0.2$ doz idi ve tam hasta uyumu \%10 olarak bulundu. Doz aral1kları $37.2 \pm$ 6.15 gün olarak bulundu. 15 hastada (\%60) ASYE ve solunum sıkıntısı nedeniyle çoklu acil servis başvuruları ve bronkodilatatör tedavi alma hikayesi mevcuttu. 10 hastada (\%40) ASYE nedeniyle hastaneye yatış ve RSV izolasyonu mevcuttu. Hastaneye yatıș süreleri ortalama $8 \pm 4.5$ gün idi. HLHS tanılı $1(\% 4)$ hastada RSV enfeksiyonuna bağl1, 8 gün yoğun bakım takibi, 3 gün mekanik ventilasyon gereksinimi ve 10 gün servis izlemi kaydedildi.

Ekim 2017-Mart 2018sezonunda; bir önceki sezonda proflaksideki düşük hasta uyumu ve RSV'ye bağlı yüksek hastane yatış oranları göz önünde bulundurularak değiştirilmiş palivizumab proflaksisi uygulama ve takip protokolüne ait detaylar tespit edildi. 2. Sezonda uygulanan protokolde tespit edilen değişikliklerin aşağıdaki gibi olduğu kaydedildi;

- Yil içerisinde RSV proflaksisi için aday olan hastalar ayrı bir çalışma sayfasında toplandı

- Daha önce tanı almış ve takipte olan hastalar Ekim ayının ilk haftasında klinik ve ekokardiyografik olarak tekrar değerlendirildi ve proflaksi alacak hastalar belirlendi.

- Proflaksi almasi gereken hastaların aileleri takip eden tek bir pediyatrik kardiyoloji hekimi tarafindan konjenital kalp hastalarında RSV enfeksiyonu, enfeksiyon seyri ve aşılama ile ilgili detaylı olarak bilgilendirildi.

- Proflaksi alacak hastalar için bir örneği annede ve bir örneği kliniğimizde kalacak şekilde ayrı bir takip dosyası oluşturuldu. Bu takip dosyasında hekimin hastaya, hastanın hekime ulaşabileceği iletișim numaraları bulunmakta idi.

- $\quad$ Ekim ayının ilk haftası aşı yapacak, kayıtları tutacak yardımcı sağlık personeli ekibi ve asistanlar için eğitim toplantısı yapıldı.

Aşılama için haftada bir gün belirlendi ve tüm ekip bu konuda bilgilendirildi.

- Aşılama çocuk kardiyolojisi servisinde eğitim alan hemşireler tarafından hekim gözeteminde yapild1.
- Aş1lama yapıldıktan sonra bir sonraki randevu tarihi ve saati belirlendi ve aileye yazılı olarak verildi ve hastane kayıtlarına işlendi.

- $\quad$ Ailelere randevu gününden iki gün önce hatırlatma çağrısı yapıldı.

- Her ayın son haftasinda hastalar taranarak gelmeyen hastalar belirlendi, hastalar aranarak aşılama yapilmama sebebi soruldu ve kaydedildi, uygun olan en yakin tarih ve saate tekrar randevu verildi.

Mart 2017- Ekim 2018 sezonunda tüm hastaların 5 aylık sezon sürecince toplam 4 doz proflaksi aldığ 1 tespit edildi, doz aralıkları ortalama $31 \pm 0.52$ olarak bulundu ve hasta uyumu \%100 olarak değerlendirildi. Bu sezonda ASYE nedeniyle acil servis başvurusu ve hastaneye yatış gereksinimi tespit edilmedi.

2 sezonda da proflakside kullanılan etken maddeye karşı herhangi bir reaksiyon görülmedi.

Doz uyumu ve doz aralikları açısından iki sezon karşılaştırıldığında 2. sezonda doz uyumu anlamlı şeklilde artmıştır $(\mathrm{p}<0.001)$ ve doz aralıkları anlamlı şekilde kısalmıştır $(\mathrm{p}<0.001)$. ASYE nedeniyle hastane bașvuru 2. Sezonda anlamlı şekilde azalmıştır $(\mathrm{p}<0.001)$.

\section{TARTIŞMA}

Frogel ve ark. nin palivizumab proflaksisinde hasta uyumunu değerlendiren derlemesinde, geniş bir literatür taraması yapmışlar ve RSV proflaksisinde hasta uyumunun \%25-\%100 arasında değiştiğini göstermişlerdir (12). Bu derlemede ebeveynlerin proflaksi yararı ve RSV enfeksiyonu ile ilgili bilgilendirilmesinin, uygulamayı yapan personelin eğitiminin ve uygulamaların evde yapılmasının uyumu arttırdığını ve artan uyumla birlikte hastaneye yatış oranlarının düştüğünü göstermişlerdir. Ancak yaptıkları derlemede uyumu arttıran protokollerle ilgili k1sıtlı bilgi olduğunu belitmișlerdir. Bizim çalışmamızda değişen ve uyumun arttığı protokolde, uygulama evde yapılmamıştır ancak hasta ve ebeveynlere daha güvenli ve konforlu bir ortam sağlamak amacıyla uygulama servis ortamında yapılmış ve uyumu arttırdığı gözlenmiştir.

Langkamp ve ark. nın yaptığı uyum çalışmasinda, uyumu etkileyen en önemli faktörün ebeveyn alg1sı olduğunu söylemişlerdir (15). Bizim çalışmamıza benzer şekilde, çalışmalarında ve ebeveynlerinin proflaksinin yararı ve enfeksiyonun seyri ile ilgili bilgilendirilmesinin uyumu arttırdığını söylemişlerdir.

Borecka ve ark. nın yaptığı uyum çalışmasında, ardışık 2 sezonu değerlendirmişler ve 2 . sezonda uyumun arttığını ve solunum yolu enfeksiyonlarının azaldığını göstermişlerdir (13). Bizim çalışmamıza benzer şekilde, uyumdaki artış1 ailelerin 2. sezonda bilgilendirilmiş olmasına ve uygulama yapan ekibin bilgi ve deneyiminin artmış olmasına bağlamışlardır.

Çalışmamıza benzer şekilde, doz uyumu kadar, aylık doz uygulama süresinin solunum sistemi hastalıkları nedeniyle hastaneye başvuruları üzerine etkisini gösteren ve aylık doz uygulanmasinın önemine dikkat çeken çalışmalar bulunmaktadır(16-18).

Pignotti ve ark. nın protokollerin uyum üzerine etkisini araştıran çalışmalarında, ebeveynlere 
proflaksisin yararı ve RSV enfeksiyonun risklerini belirten detaylı açıklamalar yazılı olarak verildikten sonra uyumun \%80' den \%88'e çıktığ 1 gösterilmiştir (19).

Yapılmış olan diğer çalışmalara benzer olarak, bizim çalışmamızda ebeveynlerin detaylı olarak ve özellikle takip ve tedaviyi yapan hekim tarafindan bilgilendirilmesinin ve bir sonraki randevu tarihinin hem aile hem uygulamayı yapacak personel tarafindan kayıt edilmesi ve uygulama önce hatırlatma çağrılarının yapılmasının uyum üzerine son derece etkili olduğunu düşünmekteyiz. Bunun yanı sıra uygulamayı yapan sağlık personelinin bilgilendirilmiş olmas1 ve uygulamanın servis ortamında daha konforlu ve güvenli bir şekilde yapılmasının da uyum üzerine etkili olduğunu düşünmekteyiz.

\section{Kisitlamalar}

$\mathrm{Bu}$ uygulama protokolü ile daha fazla hasta sayısı ile, daha uzun çalışmalara ihtiyaç vardır.

\section{SONUÇ}

RSV enfeksiyonuna bağlı ASYE'larının tedavisinde etkin bir tedavi bulunmamaktadır. Palivizumab, yüksek riskli çocuklarda RSV önlenmesinde iyi tolere edilen, güvenli bir monoklonal antikordur. Palivizumab proflaksisinde doz tamamlanması ve aralığ1 uyumunu arttırmak RSV'ye bağlı hastane yatışlarını önemli ölçülde azaltmaktadır. Detaylı ve iyi organize edilmiş takip ve uygulama protokolleri hazırlanmak uyumu arttırmada son derece önemlidir.

\section{KAYNAKLAR}

1. Glezen WP, Taber LH, Frank AL, Kasel J. Risk of primary infection and reinfection with respiratory syncytial virüs. Am J Dis Child. 1986; 140: 543-546

2. Nair H, Nokes DJ, Gessner BD, et al. Global burden of acute lower respiratory infections due to respiratory syncytial virüs in young children: a systematic review and meta-analysis. Lancet. 2010; 375: 1545-1555

3. MacDonald NE, Hall CB, Suffin SC, Alexson C, Harris PJ, Manning JA. Respiratory syncytial viral infection in infants with congenital heart disease. N Engl J Med 1982; 307: 397-400.

4. Wang EE, Law BJ, Robinson JL, et al. PICNIC (Pediatric Investigators Collaborative Network on Infections in Canada) study of the role of age and respiratory syncytial virus neutralizing antibody on respiratory syncytial virus illness in patients with underlying heart or lung disease. Pediatrics 1997; 99: E4

5. Altman CA, Englund JA, Sunnegardh J, et al. Evaluating national guidelines fort he prophylactic treatment of respiratory syncytial virüs in children with congenital heart disease. Acta Paediatr. 2014; 103: $840-845$

6. Khongphatthanayothin A, Wong PC, Samara Y, et al. Impact of respiratory syncytial virus infection on surgery for congenital heart disease: a contemporary look at epidemiology and success of preoperative screening. Pediatr Cardiol. 2000; 21: 433-438

7. Mullins Ja, La Monte AC, Brsee JS, Anderson LJ. Substantial variability in community respiratory syncytial virus season timing. Pediatr Infect Dis J. 2003; 22: 857-862

8. Impact- RSV Study Group. Palivizumab, a human respiratory syncytial virus monoclonal antibody, reduces hospitalization from respiratory syncytial virus infection in high risk infants. Pediatrics. 1998; 102; $531-537$
9. Feltes TF, Cabalka AK, Meissner HC, et al. Cardiac Synagis Study Group. Palivizumab prophylaxis reduces hospitalization due to respiratory syncytial virus in young children with hemodinamically significant congenital heart disease. J Pediatr. 2003; 143: 532-540

10. Feltes TF, Sondheimer HM, Tulloh RM, et al. Motavizumab Cardiac Study Group. A randomized controlled trial of motavizumab versus palivizumab for the prophylaxis of serious respiratory syncytial virus disease in children with hemodinamically significant congenital heart disease. Pediatr Res. 2011; 70: 186-191

11. Subramanian KN, Weisman LE, Rhodes T, et al. Safety and pharmacokinetics of a humanized monoclonal antibody to respiratory syncytial virus in prematüre infants with bronchopulmonary dysplasia. Pediatr Infect Dis J. 1998; 17: 110-115

12. Frogel MP, Stewart DL, Hoopes M. A systematic review of compliance with palivizumab administration for RSV immunoprophylaxis. JMCP. 2010; 16: 46-56

13. Borecka R, Lauterbach R, Helwich E. Factors related to compliance with palivizumab prophylaxis for respiratuar syncytial virus infection-Data Poland. Dev Period Med. 2016; 3:181-190

14. Li A, Wang D, Lanctot $K$. Comparing first and second year palivizumab prophylaxis in patients with hemodynamically significant congenital heart disease in cares database (2005-2015). Pediatr Infect Dis J. 2017; 36: 445- 450

15. Langkamp DL, Hlavin SM, Bowen M. Compliance with palivizumab. Pediatr Res. 2002; 51:297 A. Poster presented at American pediatric Society/ Society for Pediatric Research Annual Meeting. May 4-7.2002. Baltimore

16. Krilov LR, Masaquel AS, Weiner LB, Smith DM, Wade SW, Mahadevia PJ. Partial palivizumab prophylaxis and increased risk of hospitalization due to respiratory syncytial virus in a Medical population: a retrospective cohort analysis. BMC Pediatr. 2014; 14: 261-261

17. Oh PI, Lanctot KI, Yoon A, et al. Palivizumab prophylaxis for respiratory syncytial virus in Canada: utilization and outcomes. Pediatr Infect Dis J. 2002; 21: 512-518

18. Stewart DI, Ryan KJ, Seare JG, Pinsky B, Becker L, Frogel M. Association of $R S V$-related hospitalization and non-compliance with palivizumab among commercially insured infants: a retrospective analysis. BMC Infect Dis J. 2008; 53: 175-176

19. Pignotti MS, Indolli $G$, Donzelli G. Factors impacting compliance with palivizumab prophylaxis. Pediatr Infect Dis J. 2004; 23: 186-187. 